\title{
Intellectual Capital and Corporate Performance: \\ Evidence From Banking Industry of Bangladesh
}

\author{
Md Nur Nabi \\ College of Humanities and Development Studies, China Agricultural University, \\ Beijing-100193, P. R. China \\ E-mail: nurnabicau@cau.edu.cn \\ Qijie Gao (Corresponding Author) \\ College of Humanities and Development Studies, China Agricultural University, \\ Beijing-100193, P. R. China \\ E-mail: gqijie1963@gmail.com
}

\begin{abstract}
Md Takibur Rahman
Faculty of Business Administration and Management, Patuakhali Science and Technology University, Patuakhali-8602, Bangladesh

E-mail: takibctg@yahoo.com
\end{abstract}

Shaun O. Britton

Deputy Regional Executive Officer, Planning Potaro Siparuni, Guyana

E-mail: Shaun_britton2004@yahoo.com

Mohammad Muzahidul Islam

Faculty of Business Administration and Management, Patuakhali Science and Technology University, Patuakhali-8602, Bangladesh

E-mail: muzahidhrm@gmail.com

Received: Dec. 29, 2019 Accepted: Jan. 21, 2020 Online published: Feb. 1, 2020

doi:10.5296/ijhrs.v10i1.16146 URL: https://doi.org/10.5296/ijhrs.v10i1.16146 


\section{$\triangle$ Macrothink}

\section{Abstract}

Intellectual capital (IC) is about the greatest competitive weapon for an organizational development. It becomes the most significant factor in the organization's economic life. Therefore, the purpose of this paper is to examine the relationship between intellectual capital (IC) and corporate performance of the banking industry. This study used econometric models against five years of panel data from 2012 to 2016 of commercial banks in Bangladesh. The empirical study revealed a positive and significant relationship between value added intellectual capital (VAIC) and banks' performances. Further, only capital employed efficiency (CEE) as a component of VAIC has a significant relationship with banks' performance. In addition, structural capital efficiency (SCE) has a very high degree of moderating power on CEE which can be transformed into corporate performance. This study enriches the existing literature of IC and corporate performance and it may be beneficial for the sustainable economic performances of banking industry of Bangladesh.

Keywords: intellectual capital, human capital efficiency, structural capital efficiency, capital employed efficiency, moderating power, Bangladesh

\section{Introduction}

In a dynamic and competitive environment, intangible assets are being considered as important as tangible assets and even more in some cases; instances include but are not limited to Amazon, Microsoft, Wal-Mart, Google (Marr, Gray, \& Neely, 2003). The tangible assets like plants and equipment were the core capital of production and corporate performance in the industrial age. While in the post-industrial age, knowledge-based industries are growing and there has been a shift from tangible to intangible assets where, IC is considered as the core capital of production as well as corporate performance (Canibano, Garcia-Ayuso, \& Sanchez, 2000; Flamholtz, 1999). Similarly, IC is highlighted in early empirical works as an important asset for business success and an invaluable source of competitive advantages (Hamzah \& Ismail, 2008). For example, the argument of Riahi-Belkaoui (2003) is that tangible and intangible assets are working as strategic assets which create competitive advantages for better performance. As a strategic asset IC is being considered due to its ability to create competitive advantages which are related to the interest of firm owners. However, a universally accepted definition of intellectual capital is yet obscure.

Early studies interchangeably used the intangible assets and intellectual capital. For example, Edvission and Malone (1997) indicate that IC can be comprised of knowledge, applied technologies, experiences, customer's linkage, and organizational professional skills. Whereas Porter (1999), argued that IC is composed of structural, human and relational capital. Later Pulic (2000) outlined that IC is the qualities and capabilities of employees that are used to create the value of a firm. In the same vein of Pulic (2000), Roos, Pike, and Fernstrom (2005) defined IC as the nonphysical and nonmonetary assets that are partly or entirely controlled by a firm and which plays a vital role in creating the firm value. Furthermore, Scafarto (2016), stated that IC is premised on four capitals namely - human capital (HC), process capital (PrC), innovation capital ( $\mathrm{InnC})$ and relational capital (RC). Although the 
available literature gives an elaborative and necessary structure for a clear understanding of IC, there is however, a lack of specificity for the identification and measurement of IC. Problems also arise while investigating the relationship between IC and corporate performance as it is not presented with financial statements or any other reports.

Since there is no concrete way of identifying and measuring IC, many researchers initiated the measurement of IC at different times in different ways. The way IC is measured a bit different in different literatures. For instance Tovstiga and Tulugurova (2007) used the intangible assets monitor, while Kaplan and Norton (1992) considered the balanced scorecard method. Further, Cummins and Weiss (2013) shows that previous researchers applied different productivity and frontier analysis methods to examine companies' performance. Aside from those methods Riahi-Belkaoui (2003) used the RVATA (Relative Value Added over Total Assets) method to examine IC efficiency. Most recently is Torres, Silvana, and Santos-Rodrigues (2018) who applied a different method on Portuguese data of SMEs that measures the relations between different knowledge management (KM) factors on sustainable corporate advantages (CA). In addition, some variables have been accepted to investigate the relationship between IC and corporate performance; for example, human capital, structural capital, consumer capital, research and development expenditure, etc. None the less, it is still temporary and ambiguous to calculate the impact of IC value and efficiency on company performance (Sanchez \& Elena, 2006).

Consequently, an indirect measurement system named value-added intellectual capital (VAIC) was developed by Pulic (2000), which measures the efficiency of IC to value-added in a firm. It also gives information about the level of efficiency of intangible and tangible assets. According to, Sardo and Serrasqueiro (2018) as cited in Zéghal and Maaloul (2010), the UK's Department of Business, Innovation and Skills adopted VAIC as the indicator of firms' IC, which highly validates VAIC as a model. Following Pulic (2000), Kujansivu and Lonnqvist (2007) employed 20,000 sample firms from eleven dominating industries in Finland in their study during 2001 to 2003. They used the Calculated Intangible Value (CIV) method for measuring VAIC and IC's accounting value in order to calculate the value added by the firm's IC. Therefore it is evident that VAIC is a commonly accepted model to determine IC and its impact on firms' performance.

As the significance of IC is reflected as a necessity in the rising concentration of emerging and service sectors, many studies have been conducted to identify the contribution of IC on the corporate performance of different industries in different locations in the world. Many of them used VAIC model as it is widely accepted and popularly applied in this respect. The most exemplary studies in this respect are in the United Kingdom (UK), measuring firm's intellectual performance on Northern European SME enterprises (Roos \& Roos, 1997), human capital and technical efficiency of British retail sector (Sena, 2011). In the USA, how intellectual capital moved as the highest competitive weapon of an economic unit (Stewart, 1997). Riahi-Belkaoui (2003) examined multinational financial companies in the USA and found there is a positive influence of IC on corporate performance. Recently, Antonio, Claudio, Gabriele, and Vincenzo (2016) measured the impact of IC on the performance of US commercial banks. They modeled and demonstrated that IC efficiency of US banks positively 
affected financial performance. In the same vein studies were conducted in different countries namely, Firer and Stainbank (2003) works in high knowledge-base sectors of South Africa; Chen, Cheng, and Hwang (2005) investigated Taiwanese firms; Yalama and Coskun (2007) banking companies of Turkey; Tan, Plowman, and Hancock (2008) Singapore stock exchange listed companies; Lu, Wang, and Kweh (2014) Chinese life insurance companies; Gopal and Mitra (2016) Indian_knowledge-based and traditional sectors, and all of them revealed that IC has a positive and significant relationship with corporate performance. Corroborating with the preceeding studies are those from Portugal (Cabrita \& Bontis, 2008); Hong Kong (Chu, Chan, Yu, Ng, \& Wong, 2011); Ghana (Latif \& Nicholas, 2016); Arab region (Dzenopoljac, Yaacoub, Elkanj, \& Bontis, 2017); Malaysia (Khalique, Bontis, Shaari, \& Yaacob, 2018); and Europe (Sardo \& Serrasqueiro, 2018) also revealed that IC has positive effects on corporate performance. Above results also concurred with the results of many other researchers who reported that IC or intangible assets could contribute more to high performance and create competitive advantages compared to tangible assets.

Another fraction of studies highlights the contribution of IC components, which comprises human capital and structural capital to gain sustainable competitive advantages (Kaplan \& Norton, 2004). There are some studies that used components of IC and also found diversified positive connection between components of IC and company performance. For instance, Cabrita and Bontis (2008) assessed the banking industry of Portugal, and found human capital to be the most significant capital utilized by banks. Aligning with this findings are Mavridis (2004) who studied Japanese banks; Bollen, Vergauwen, and Schnieders (2005) who studied a German dataset; Cohen and Kaimenakis (2007) who considared Greek knowledge-intensive SMEs; Clarke, Seng, and Whiting (2011) who examined the effect of IC on Australian companies' performances; Sumedrea (2013) who used a Romanian dataset and all of them discovered a positive and significant association between IC components and firm performance, though the results are diverse. Recently, Khalique et al (2018) used Malaysian knowledge-intensive SMEs, and the results indicate that the human capital, technological capital, customer capital, social capital, structural capital and spiritual capital are significant components of intellectual capital and all of these capitals are linked to institutional performance.

In contrast, Firer and Williams (2003) investigated listed public companies of South Africa and Gan and Saleh (2008) used data from Malaysian technology-based companies; they did not find a positive nor significant impact of IC on corporate performance. Janosević, Dzenopoljac, and Bontis (2013) \& Grant (2007) findings were similar to that of Firer and Williams (2003). Aside from those, Puntillo (2009) did not find any conclusive and significant relationship between IC and corporate performance. In the same vein Appuhami (2007) investigated an insignificant and negative connection of IC components and corporate performance. The conflicting results of earlier researchers failed to establish a concrete position on the relations between IC and corporate performance.

Stimulated by these flows of arguments, this study intends to explore the contribution of IC to the performance of the banking industry in Bangladesh. Further, this study thought the time is most appropriate to research this realm; because the industry in recent years has been 
enduring a crucial period due to the high competition, the rapid growth in the number of banks, and the small market-size of the banking industry in Bangladesh. This has influenced banks to undertake negative operation to survive in the market and it is reflected in their profitability level (ROA); non-performing loans (NPL); and bad loans (Appendix-A). Overall general picture shows that ROA is deteriorating year to year, percent of NPL and the amount of bad loan is increasing year to year. As a result, it is crucial to improve their performance, and corporate performance mainly depends on IC (Canibano et al, 2000; Flamholtz, 1999). Therefore it is important to explore how well the banks utilize their IC to achieve better performances. However, no study has been conducted in this subject on the banking sector of Bangladesh although it's a highly IC intensive industry. With these facts in mind, this study intends to measure the association of IC on banks performance of Bangladesh using VAIC approach. Thus, the focus research question of this paper is: whether IC efficiency has a positive relationship with the performance of the banking industry of Bangladesh? An additional research question is posed: whether the bank's IC efficiency has any moderating power on the relationship between CEE and bank performance?

The next section of this paper will outline the hypothesis of this empirical research. This will be followed by the methodology then the results and discussion. The conclusion and policy implication will be articulated in the finale.

\section{Hypothesis}

Consistent with Alipour (2012) and Bollen et al (2005) this study set the following hypothesis related to IC and firm performance.

H.1a: There is a significant positive relationship between VAIC and corporate performance.

Earlier studies have proven the powerful contribution of different components of IC to firm performance, for instance, Appuhami (2007); Ozkan, Cakan, and Kayacan (2017); Chen et al (2005); Kujansivu and Lonnqvist (2007); Ousama and Fatima (2015); Pulic (1998). The study used three IC components namely human capital, structural capital, and capital employed. Thus following Seleim, Ashour, and Bontis (2004), this study can build three hypotheses in this aspect: There is a significant positive relationship between (H.2a) human capital efficiency (HCE); (H.2b) structural capital efficiency (SCE); (H.2c) capital employed efficiency (CEE) and corporate performance.

Further, it is assumed that by using IC there is no possibility of changing the firm's performance instantly. Therefore, following Clarke et al (2011) this study can hypothesise that the current year's VAIC and its components could create an impact on pursuing a year corporate performance and the following four hypotheses constructed in this connection: (H.1aL) the previous year's VAIC has a positive and significant relationship with current year corporate performance. Similarly, (H.2aL) the previous year's HCE; (H.2bL) previous year's SCE; and (H.2cL) previous year's CEE have a positive and significant relationship with current year corporate performance.

Although previous studies investigated the direct impact of IC efficiency on corporate performance, this study intended to find the moderating power of IC on physical assets. 
According to Pulic (1998), IC cannot generate firm's value directly by itself. It is quite impossible for the IC to uplift a firm's value unless it is being linked with financial and physical assets (Carter, Simkins, \& Simpson, 2003). Thus, this study can make a hypothesis where IC can moderate the capital employed efficiency in connection to corporate performance. Hence, this study developed the following hypotheses: (H.3a) HCE; and (H.3b) SCE positively moderates the CEE which is transformed into corporate performance.

\section{Methodology}

\subsection{Data and Sources}

This study adopted the Dhaka Stock Exchange (DSE) listed commercial banks, five years of annual data with span from 2012 to 2016 . It is considered 28 banks purposively out of thirty. Two banks out of thirty were excluded due to abnormally inconsistent financial performance over the studied period.

\subsection{Operationalization of the Study Variables}

\subsubsection{Dependent Variables}

The financial indicators which are perceived as the fulfillment of financial goals of a firm is called Corporate performance (Venkatraman \& Ramanujam, 1986). Here all corporate performance indicators are used as the dependent variables. To calculate the corporate performance, there are two widely accepted approaches that exist, such as the accounting approach and the market-based approach. Earlier research, for example, that of Dzenopoljac et al (2017) and others used accounting approach included Return on Assets (ROA), Return on Capital (ROC) or Return on Sales (ROS), and Net Profit Margin (NPM). On the other hand, the market-based approach used the Sharpe ratio, Jensen's Alpha, Treynor ratio, Earnings per share and Tobin's Q (TQ) to measure corporate performance. These are related to the financial market status of a firm.

This study is guided by prior researchers in this subject (Dzenopoljac et al, 2017; Iazzolino, Migliano, \& Gregorace, 2013; Tasawar, Haniffa, \& Hudaib, 2014) and adopted the following measures of corporate performance: Return on Assets (ROA), Return on Equity (ROE), Return on Capital (ROC), Earning per Share (EPS), Tobin's Q (TQ), Employee Productivity (EP) and Growth Opportunity (GO).

\subsubsection{Explanatory Variables}

Similar to Chen et al (2005), this study is investigating the degree of relationship that exists between IC and corporate performance. Here, the study used explanatory variables namely VAIC and components of VAIC namely (a) HCE, (b) SCE and (c) CEE as guided by Pulic (1998).

\subsubsection{Control Variables}

Riahi-Belkaoui (2003) indicates the leverage ratio of a firm is a significant determinant for value addition and performance. Further, Firer and Williams (2003) argued large firm size and firm age is a matter of performance and involves firm complexities. Therefore, this study 
incorporated three additional variables namely, firm leverage (LEV), age (AGE), and size (SIZE) in the econometric models to lessen the influence of additional variables these could describe the impact of VAIC on corporate performance. Table 1 presents the variables and their computation formulas.

Table 1. Variables and their computation formulas

\begin{tabular}{|c|c|c|}
\hline Variables full name & $\begin{array}{l}\text { Variables } \\
\text { short name }\end{array}$ & Variables Calculating formulas \\
\hline \multicolumn{3}{|c|}{ a) Dependent Variables (Corporate performance Measures) } \\
\hline Return on Assets & ROA & Net profit / Total Assets \\
\hline Return on Equity & ROE & Net profit / Total Equity \\
\hline Return on Capital & ROC & Net profit / Outstanding capital \\
\hline Earnings Per Share & EPS & $\begin{array}{l}\text { (Net profit - Dividends on Preferred Stock) / } \\
\text { Average Outstanding Shares }\end{array}$ \\
\hline Employee Productivity & EP & $\begin{array}{l}\text { Output / Input or Net Profit / Employees } \\
\text { Number }\end{array}$ \\
\hline Growth Opportunities & GO & Per year total assets increase in percentage \\
\hline Tobin's Q & TQ & $\begin{array}{l}\text { Total market value of firm/Total assets value of } \\
\text { firm }\end{array}$ \\
\hline \multicolumn{3}{|c|}{ b) Explanatory Variables (VAIC and its components) } \\
\hline Human Capital Efficiency & $\mathrm{HCE}$ & VA / HC Where, VA=Value Added \\
\hline Structural Capital Efficiency & SCE & $\mathrm{SC} / \mathrm{VA}$ \\
\hline Capital Employed Efficiency & $\mathrm{CEE}$ & $\mathrm{VA} / \mathrm{CE}$ \\
\hline $\begin{array}{l}\text { Value Added Intellectual } \\
\text { Capital }\end{array}$ & VAIC & $\mathrm{HCE}+\mathrm{SCE}+\mathrm{CEE}$ \\
\hline Human Capital & $\mathrm{HC}$ & $\begin{array}{l}\text { Proxies by Salaries and Administrative } \\
\text { Expenses }\end{array}$ \\
\hline Structural Capital & $\mathrm{SC}$ & $\mathrm{VA}-\mathrm{HC}$ \\
\hline Capital Employed & $\mathrm{CE}$ & Total Assets - Intangible or other Assets \\
\hline \multicolumn{3}{|l|}{ c) Control variables } \\
\hline Leverage & LEV & Total Debt / Total Assets \\
\hline Firm Age & AGE & $\begin{array}{l}\mathrm{LN} \text { of firm age (age }=\text { Number of year since } \\
\text { inception) }\end{array}$ \\
\hline Firm Size & SIZE & LN of total assets \\
\hline
\end{tabular}

\subsection{Models}

Reflecting on the hypotheses set in section two, to test these hypotheses this study build the following models. In the first stage, the study builds the following two models, which are connected with hypotheses H.1a and H.1aL. More particularly, these two models examined the relationship of VAIC and lagged VAIC with corporate performance respectively.

$$
\begin{gathered}
\text { Model-01: Pef } k=\alpha+\beta_{1} \text { VAIC }_{k, t}+\beta_{2} L E V_{k, t}+\beta_{3} A G E_{k, t}+\beta_{4} S I Z E_{k, t}+\varepsilon_{k, t} \\
\text { Model-02: Pef } k=\alpha+\beta_{1} \text { VAIC }_{k, t}+\beta_{2} \text { VAIC }_{k, t-1}+\beta_{3} L E V_{k, t}+\beta_{4} A G E_{k, t}+\beta_{5} S I Z E_{k, t}+\varepsilon_{k, t}
\end{gathered}
$$




\section{MInstitute Macrothink $^{\text {Int }}$}

This study set the model 3 to test the hypotheses H.2a, H.2b and H.2c.

$$
\text { Model - 03: } P e f_{k, t}=\alpha+\beta_{1} H C E_{k, t}+\beta_{2} S C E_{k, t}+\beta_{3} C E E_{k, t}+\beta_{4} L E V_{k, t}+\beta_{5} A G E_{k, t}+\beta_{6} S I Z E_{k, t}+\varepsilon_{k, t}
$$

The lagged VAIC components related to hypotheses H.2aL, H.2bL, and H.2cL will be tested using the following model-4. Here considered the lagged VAIC components in the model-03.

$$
\begin{gathered}
\text { Model-04: } \text { Pef }_{k, t}=\alpha+\beta_{1} H C E_{k, t}+\beta_{2} S C E_{k, t}+\beta_{3} C E E_{k, t}+\beta_{4} H C E_{k, t-1}+\beta_{5} S C E_{k, t-1}+\beta_{6} C E E_{k, t-1} \\
+\beta_{7} L E V_{k, t}+\beta_{8} A G E_{k, t}+\beta_{9} S I Z E_{k, t}+\varepsilon_{k, t}
\end{gathered}
$$

In the four models mentioned above this study used different dependent, independent and control variables. For clarity, the basic meanings of every element of these models are as follows. Where, $P e f_{k, t}$ Stand for corporate performance measures, which includes 7 (seven) measures listed in the table-2. The right-hand side of the models are VAIC and VAIC $C_{i, t-1}$ means value added intellectual capital and lagged VAIC. Where, $H C E$ and $H C E_{i, t-1}, S C E$ and $S C E_{i, t-1}$, $C E E$ and $C E E_{i, t-1}$ presents the current and lagged human capital efficiency; structural capital efficiency; and capital employed efficiency respectively. The other common components of the right-hand sides are control variables listed in the table-2. Each model has to run seven times for the seven performance measures. Each dependent variable (performance measure) of the specific model has to run for one time to interact with the specific set of independent (explanatory) variables.

The following two steps are used to calculate the human and structural capital moderating power in the connection to IC and corporate performance (hypotheses: H.3a and H.3b): firstly, this study measures the relationship between each performance measure and all control variables as independent variables. Therefore this study developed the following model:

$$
\text { Model - 05: } \text { Pef }_{k, t}=\alpha+\sum_{k=1}^{3} \beta_{n} \operatorname{CONT}_{k, t}+\varepsilon_{k, t}
$$

Or

$$
\operatorname{Pef}_{\mathrm{k}, \mathrm{t}}=\alpha+\beta_{1} \mathrm{LEV}_{\mathrm{k}, \mathrm{t}}+\beta_{2} \mathrm{AGE}_{\mathrm{k}, \mathrm{t}}+\beta_{3} \mathrm{SIZE}_{\mathrm{k}, \mathrm{t}}+\varepsilon_{\mathrm{k}, \mathrm{t}}
$$

Hence, it excludes the impact of control variables. After a regression of control variables with performance measures is done, the obtained residuals imply the variance which is not explained by the listed control variables. According to Clarke et al (2011) whenever a study uses a series of residual variables as dependent variables for measuring the relationship between VAIC components and corporate performance, the study can explained it's research objective more effectively than the control variables able to explain. Therefore, this paper applied this method to get the effective outcomes related the hypotheses H.3a and H.3b. Secondly, this study regress the $P e f_{\text {resid } k, t}$ values found from the earlier model (05) to examine the moderating power of VAIC components. An econometric model that use the multiplicative terms is able to capture the moderating effects according to Jaccard and Turrisi (2003). Therefore, this study adopted $\left(\mathrm{SCE}_{k, t}\right) *\left(\mathrm{CEE}_{\mathrm{k}, \mathrm{t}}\right)$; and $\left(\mathrm{HCE}_{\mathrm{k}, \mathrm{t}}\right) *\left(\mathrm{CEE}_{\mathrm{k}, \mathrm{t}}\right)$ as 
multiplicative variables. As a result, it has used the following models to examine the explanatory power of the VAIC components and the interaction impact of these components on corporate performance:

Model-06: Pef resid $k, t=\alpha+\beta_{1} H C E_{k, t}+\beta_{2} S C E_{k, t}+\beta_{3} C E E_{k, t}+\beta_{4}\left(H C E_{k, t}\right) *\left(C E E_{k, t}\right)+\beta_{5}(S C E$

$$
k, t) *\left(C E E_{k, t}\right)+\varepsilon_{k, t}
$$

Further, this study added the lagged effect of VAIC components in this model based on Clarke et al (2011)_and constructed model-07 at this point:

$$
\begin{gathered}
\text { Model-07: } P e f_{\text {resid } k, t}=\alpha+\beta_{1} H C E_{k, t}+\beta_{2} S C E_{k, t}+\beta_{3} C E E_{k, t}+\beta_{4} H C E_{k, t-1}+\beta_{5} S C E_{k, t-1}+ \\
\beta_{6} C E E_{k, t-1}+\beta_{7}\left(H C E_{k, t}\right) *\left(C E E_{k, t}\right)+\beta_{8}\left(S C E_{k, t}\right) *\left(C E E_{k, t}\right)+\varepsilon_{k, t}
\end{gathered}
$$

\subsection{Methods}

The main objective of this study is to investigate the relationship between IC and performance of the banking industry in Bangladesh. Also, one microcosmic objective is to apply different sorts of methodologies and testing their effects on the empirical findings. To test these, firstly calculate a pool regression; which does not consider both unobservable heterogeneity and endogeneity problems. According to Gujarati (2004), if using any of the panel data techniques, the un-estimated time and individual firm-specific factor's un-estimated effects can be adjusted. The pool regression method is calculated by the ordinary least square (OLS) regression.

Further, this study used random effect and fixed effect panel data method which is mostly used by researchers among static panel data models to choose an appropriate model. Here Hausman (1978) specification technique has used to choose an appropriate regression model. The decision criterion of Hausman (1978) specification technique is based on p-value and hypothesis.

It is assumed that all explanatory variables are exogenous in the static panel data models; following Sardo and Serrasqueiro (2018) this study also considered the dynamic panel data models and used the Generalized Method of Moments (GMM) model as introduced by Hansen (1982). The GMM makes use of the orthogonality conditions to allow for efficient estimation in the presence of heteroscedasticity of unknown form. When using the GMM estimator to examine the accuracy of the model identification, the study used Hansen Statistics to seek out any nonexistence correlation of error term and instruments.

\section{Result and Discussion}

This paper commences the result and discussion with a summary of statistics of all variables. Table 2 shows the Mean, Median, Standard Deviation, Skewness, Kurtosis, Kolmogorov-Smirnova, Shapiro-Wilk, Minimum and Maximum values of all variables. To examine the normality of data the study used Kolmogorov-Smirnov and Shapiro-Wilk tests. It is found the p-value of 9 (nine) variables out of 14 are higher than 0.05 in the Kolmogorov-Smirnov test, and the p-value of 10 (ten) variables out of 14 is higher than 0.05 
in Shapiro-Wilk test. It indicates that the maximum numbers of variables are normally distributed. It is also found a noticeable difference between the maximum and minimum values of ROE, ROC, GO and EP.

Table 2. Summary statistics

\begin{tabular}{lcccccccccccccc}
\hline Particulars & ROA & ROE & ROC & EPS & TQ & EP & GO & VAIC & HCE & SCE & CEE & LEV & AGE & SIZE \\
\hline Mean & 1.1211 & 12.7514 & 0.2646 & 2.6774 & 1.0118 & 0.7382 & 16.0049 & 3.7356 & 3.0413 & 0.6569 & 0.0374 & 0.9097 & 2.9943 & 11.9507 \\
Median & 1.0700 & 12.7700 & 0.2500 & 2.4650 & 1.0040 & 0.6670 & 16.7050 & 3.5870 & 2.8950 & 0.6545 & 0.0370 & 0.9120 & 2.8900 & 11.9405 \\
Std. Dev. & 0.3946 & 4.0047 & 0.1281 & 1.0889 & 0.0518 & 0.3794 & 7.5959 & 0.9732 & 0.8763 & 0.0926 & 0.0116 & 0.0215 & 0.3710 & 0.3544 \\
Skewness & 0.125 & 0.085 & 0.522 & 0.536 & 0.496 & 0.755 & -0.421 & 0.322 & 0.360 & 0.016 & -0.078 & -0.156 & 0.553 & -0.093 \\
Kurtosis & -0.296 & -0.443 & -0.096 & -0.489 & 0.074 & 0.043 & -0.335 & -0.100 & -0.018 & -0.290 & -0.616 & 0.205 & -0.837 & -0.693 \\
Kolmogorov- & 0.071 & 0.045 & 0.079 & 0.100 & 0.104 & 0.087 & 0.073 & 0.073 & 0.050 & 0.045 & 0.056 & 0.065 & 0.147 & 0.054 \\
Smirnova & & & & & & & & & & & & & & \\
Sig. & 0.078 & 0.200 & 0.031 & 0.002 & 0.001 & 0.011 & 0.067 & 0.063 & 0.028 & 0.200 & 0.200 & 0.200 & 0.000 & 0.200 \\
Shapiro-wik & 0.988 & 0.995 & 0.972 & 0.962 & 0.971 & 0.948 & 0.972 & 0.974 & 0.971 & 0.993 & 0.988 & 0.988 & 0.922 & 0.984 \\
Sig & 0.291 & 0.878 & 0.005 & 0.001 & 0.005 & 0.000 & 0.006 & 0.009 & 0.004 & 0.714 & 0.271 & 0.284 & 0.000 & 0.095 \\
Min. & 0.21 & 3.02 & 0.02 & 0.55 & 0.89 & 0.07 & -5.12 & 1.44 & 0.97 & 0.43 & 0.01 & 0.86 & 2.40 & 11.12 \\
Max & 2.08 & 23.49 & 0.60 & 5.50 & 1.15 & 1.75 & 30.39 & 5.86 & 5.01 & 0.88 & 0.06 & 0.96 & 3.78 & 12.66 \\
\hline
\end{tabular}

Source: Authors calculation

Table 3. Correlation Matrix

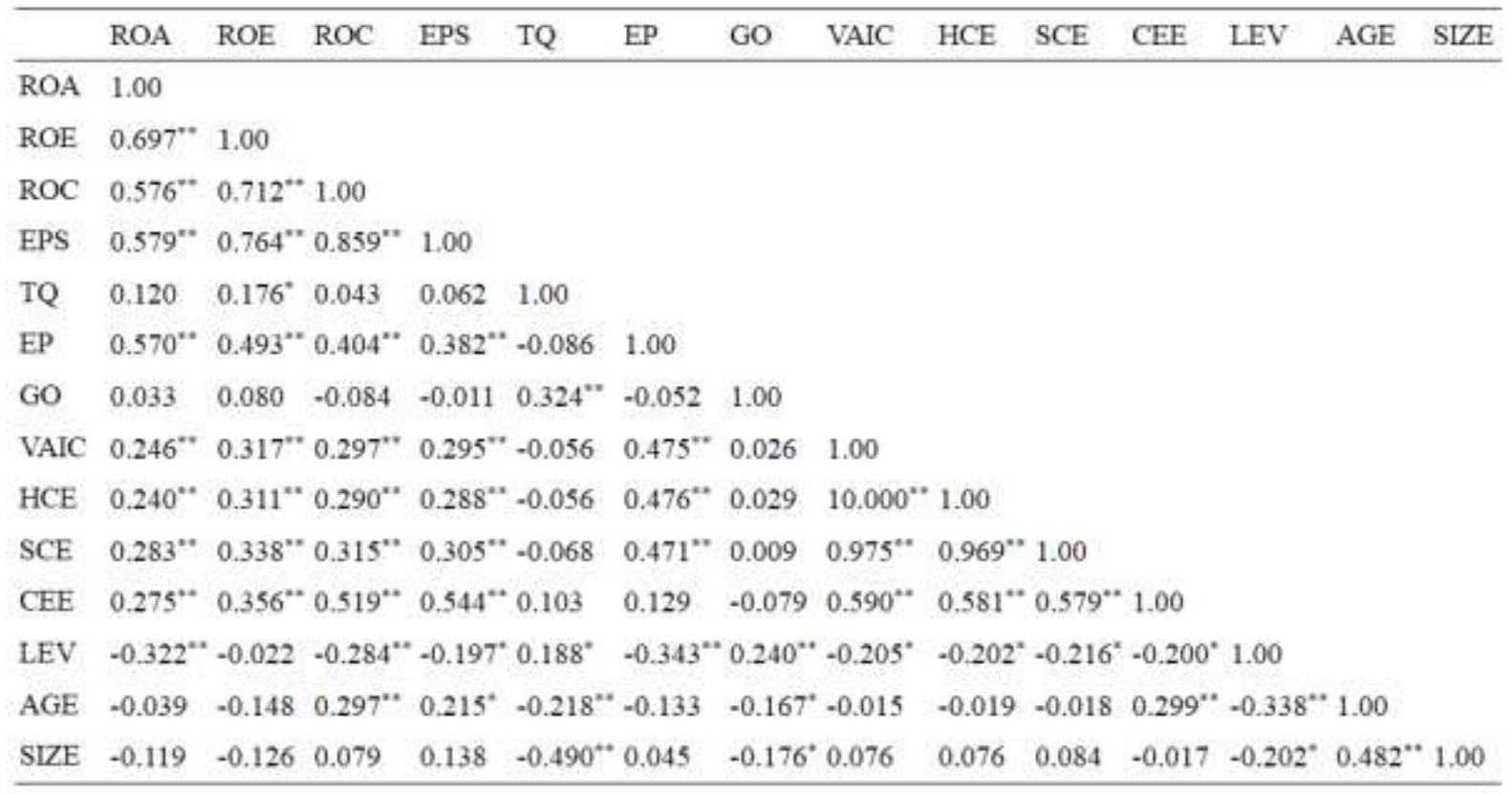

Notes: 1. *denotes correlation is significant at $10 \%$, **denotes correlation is significant at $5 \%$, $* * *$ denotes correlation is significant at $1 \%$ level. 2 . Pearson correlation is used due to the maximum number of variables are normally distributed.

Table 3 presents the correlation between the dependent and explanatory variables. Hryniewicz and Karpinski (2014) suggested that the Pearson correlation method is 
appropriate for normally distributed variables and Spearman correlation method is appropriate for abnormally distributed variables. This study adopted the Pearson correlation method because maximum numbers of variables are normally distributed. It is observed that a reasonable number of explanatory variables have a positive and significant relationship with all dependent variables individually. For instance, ROA has a significant relationship with five explanatory variables except AGE and SIZE; ROC and EPS that have a significant relationship with six explanatory variables; similarly, ROE and EP have a significant relationship with four explanatory variables; whereas TQ and GO have a significant relationship with only three explanatory variables. The results revealed most of the explanatory variables have a strong influence on the corporate performance. It has also depicted a significant inverse correlation of LEV and AGE with most of the bank's performance measures.

Table 4. Result of VAIC and corporate performance

\begin{tabular}{|c|c|c|c|c|c|c|c|}
\hline & \multicolumn{7}{|l|}{ Model 01} \\
\hline & $\mathrm{ROA}$ & ROE & $\mathrm{ROC}$ & EPS & TQ & EP & GO \\
\hline & \multicolumn{7}{|c|}{ Panel A: Pool Regression } \\
\hline$\beta_{0}$ & $8.678 * * *$ & 24.811 & $1.014 *$ & 2.072 & $1.609 * * *$ & $5.207 * * *$ & -28.707 \\
\hline$\beta_{\text {VAIC }}$ & $0.098 * * *$ & $1.461 * * *$ & $0.044 * * *$ & $0.363 * * *$ & 0.001 & $0.166^{* * *}$ & 0.993 \\
\hline$\beta_{\mathrm{LEV}}$ & $-5.825 * * *$ & 2.175 & -0.707 & -2.500 & 0.269 & $-5.556 * * *$ & $83.554 * * *$ \\
\hline$\beta_{\mathrm{AGE}}$ & -0.039 & -0.577 & $0.122 * * *$ & $0.673 * *$ & 0.008 & $-0.238 * * *$ & -0.260 \\
\hline$\beta_{\text {SIZE }}$ & $-0.210 * *$ & -1.500 & $-0.053^{*}$ & -0.044 & $-0.072 * * *$ & 0.054 & -2.873 \\
\hline $\mathrm{R}^{2}$ & 0.2044 & 0.1567 & 0.2471 & 0.1692 & 0.2507 & 0.3794 & 0.0920 \\
\hline \multirow[t]{2}{*}{ F - Value } & $8.67 * * *$ & $6.27 * * *$ & $11.07 * * *$ & $6.88 * * *$ & $11.29 * * *$ & $20.63 * * *$ & $3.42 * *$ \\
\hline & \multicolumn{7}{|c|}{ Panel B: Fixed Effect versus Random Effect } \\
\hline$\beta_{0}$ & $7.613 * * *$ & $54.813 *$ & $1.380^{* *}$ & 7.811 & $2.110 * * *$ & 2.591 & -47.545 \\
\hline$\beta_{\text {VAIC }}$ & $0.122 * * *$ & $1.962 * * *$ & $0.040 * * *$ & $0.452 * * *$ & 0.003 & $0.149 * * *$ & 0.960 \\
\hline$\beta_{\mathrm{LEV}}$ & $-4.781 * *$ & $-70.266 * *$ & $-1.221 * *$ & $-9.401 *$ & $0.555^{*}$ & $-4.515 * * *$ & 58.903 \\
\hline$\beta_{\mathrm{AGE}}$ & -0.027 & -11.5412 & $0.095^{*}$ & 0.517 & 0.029 & $-0.254 *$ & $-76.177 * * *$ \\
\hline$\beta_{\text {SIZE }}$ & $-0.211 *$ & 4.088 & -0.037 & 0.010 & $-0.142 * * *$ & $0.204 * *$ & $19.610^{* * *}$ \\
\hline $\mathrm{R}^{2}$ & 0.2102 & 0.2309 & 0.2704 & 0.2492 & 0.4837 & 0.4341 & 0.2615 \\
\hline Hausman & 1.75 & 7.12 & 2.60 & 6.69 & 38.53 & 6.66 & 29.36 \\
\hline \multirow[t]{2}{*}{ Test } & $(0.7816)$ & $(0.1299)$ & $(0.6273)$ & $(0.1532)$ & $(0.0000)$ & $(0.1552)$ & $(0.0000)$ \\
\hline & \multicolumn{7}{|c|}{ Panel C: Generalized Methods of Moments (GMM) } \\
\hline$\beta_{0}$ & 4.858 & 30.182 & -4.426 & $-86.109 * *$ & -1.362 & 18.6 & 214.783 \\
\hline$\beta_{\text {VAIC }}$ & $0.121 * *$ & $2.211 * * *$ & $0.071 * * *$ & 0.826 & 0.015 & $0.078 * *$ & -0.251 \\
\hline$\beta_{\mathrm{LEV}}$ & -2.087 & $141.415^{*}$ & $4.951^{*}$ & $88.884 * *$ & $3.065 * *$ & $-19.648 * * *$ & -153.677 \\
\hline$\beta_{\mathrm{AGE}}$ & 0.025 & 2.188 & $0.239 * * *$ & $2.460 * * *$ & $0.057 *$ & $-0.495 * * *$ & $-5.41 *$ \\
\hline$\beta_{\text {SIZE }}$ & $-0.200 * *$ & -1.927 & -0.068 & -0.232 & $-0.054 * *$ & 0.096 & -3.450 \\
\hline GMM & 0.46943 & 1.40525 & 3.07144 & 6.21565 & 7.82762 & 2.69296 & 1.41741 \\
\hline Value & $(0.4932)$ & $(0.2358)$ & $(0.0797)$ & $(0.0127)$ & $(0.0051)$ & $(0.1008)$ & $(0.2338)$ \\
\hline Hansen's & 3.44761 & 6.21725 & 6.72882 & 9.11245 & 24.6978 & 8.66401 & 10.2252 \\
\hline $\mathrm{Chi}^{2}$ & $(0.1784)$ & $(0.1447)$ & $(0.1346)$ & $(0.1105)$ & $(0.0000)$ & $(0.0131)$ & $(0.0060)$ \\
\hline
\end{tabular}


Note: *denotes $10 \%$ significant, $* *$ denotes $5 \%$ significant, $* * *$ denotes $1 \%$ significant

Table-4 presents in entirety the result of model-1 including the adopted methods of pool regression, fixed and random effect, and generalized methods of moments (GMM). Model-01 was set to examine the relations between IC as a whole and corporate performance. As seen in Panel-A (pool regression), there is supportive evidence of a strong positive relationship between VAIC and corporate performance. Noteworthy, VAIC coefficients have a positive relationship with ROA, ROE, ROC, EPS, and EP at $1 \%$ level of significance; whereas, it has a positive but insignificant relationship with TQ and GO. Here $\mathrm{R}^{2}$ values of all performance measures are at a lower level.

To eliminate the problems which occurred by the possible correlations between individual-specific dependent non-observed firm effects and the explanatory variable the study applied a static panel data model. The panel-B (fixed and random effect), also shows the same result that is shown in pooled regression. There is a significant and positive relationship between VAIC and all performance measures except TQ and GO. Here the $\mathrm{R}^{2}$ values are higher than earlier; it indicates that this model can explain more than the pool regression. The mentionable $\mathrm{R}^{2}$ value of VAIC increased in TQ, EP and GO performance measures than in the pooled regression. The Hausman test shows that the random effect model is accepted for five performance measures and the fixed effect model accepted for two performance measures. The appropriate model (random effect or fixed effect) is accepted based on the decision criterion explained in the methodology part.

In the third step, this study applied the GMM method to eliminate the endogenous problems of the explanatory variables. In general, after consideration of endogeneity problems, the findings are less significant than the previous models. In panel-C (GMM method), the study a significant and positive influence of VAIC on ROA, ROE, ROC, and EP; and the influence on TQ and EP is positive but negative on GO, however both are insignificant. Therefore, it implies that there is an endogeneity problem. As shown by the GMM statistics, all variables are exogenous except EPS and TQ. It implies that the variables are endogenous in the model EPS and TQ. The decision criterion of GMM statistics is that, if the p-value of GMM statistics is greater than 0.05 , it means the variables are exogenous for the specific model and if the p-value of GMM is less than 0.05 the variables are endogenous. Here, most of the tests found that variables are exogenous. The Hansen's $\mathrm{Chi}^{2}$ is used to test the over-identification restriction. Here the null hypothesis of the Hansen's $\mathrm{Chi}^{2}$ is that the instruments are valid instruments, i.e., the instruments are not correlated with the error term, and that the estimated equation excluded the instruments correctly. In model-01 this study found no correlation between instruments and the error term in the models of ROA, ROE, ROC, and EPS, and correlation between the instruments and the error term in the models of TQ, EP and GO. However, the panel-C (GMM method) presents that a positive and significant relationship exists between VAIC and firm performance and affirms the main research question.

It is noteworthy that, the positive relationship between corporate performance measures and VAIC found here corroborates with the findings of Antonio et al (2016), Latif and Nicholas (2016), and Sherif and Elsayed (2015). It indicates that companies with higher efficiency in 
intellectual capital contribute to a production of higher performance. Thus, the overall results of model-01 support hypothesis H.1a and ensure the attainment of the objectives of this study, which implies that the banking industry of Bangladesh indeed gets advantages from investing in their employees' knowledge and skills.

Table 5. Result of previous year's VAIC and corporate performance

\begin{tabular}{|c|c|c|c|c|c|c|c|}
\hline & \multicolumn{7}{|l|}{ Model 02} \\
\hline & ROA & ROE & $\mathrm{ROC}$ & EPS & TQ & EP & GO \\
\hline & \multicolumn{7}{|c|}{ Panel A: Pool Regression } \\
\hline$\beta_{0}$ & $8.679 * * *$ & 24.636 & $1.011^{*}$ & 2.042 & $1.601 * * *$ & $5.199 * * *$ & -28.54538 \\
\hline$\beta_{\text {VAIC }}$ & $0.109 * * *$ & $1.749 * * *$ & $0.044 * * *$ & $0.422 * * *$ & 0.001 & $0.173 * * *$ & 1.070 \\
\hline$\beta \mathrm{VAIC}_{\mathrm{t}-1}$ & -0.021 & $0.588 * *$ & -0.000 & -0.120 & -0.002 & -0.014 & $0.150 * *$ \\
\hline$\beta_{\mathrm{LEV}}$ & $-5.892 * * *$ & 0.263 & -0.709 & -2.889 & 0.259 & $-5.605 * * *$ & $83.131 * *$ \\
\hline$\beta_{\mathrm{AGE}}$ & -0.041 & -0.711 & $0.120 * * *$ & $0.647 * *$ & 0.005 & $-0.242 * * *$ & -0.216 \\
\hline$\beta_{\text {SIZE }}$ & $-0.201 * *$ & -1.208 & -0.053 & 0.013 & $-0.070 * * *$ & 0.062 & -2.839 \\
\hline $\mathrm{R}^{2}$ & 0.2072 & 0.1718 & 0.2448 & 0.1800 & 0.2555 & 0.3801 & 0.091 \\
\hline \multirow[t]{3}{*}{ F - Value } & 6.95 & 5.52 & 8.62 & 5.84 & 9.13 & 16.31 & 2.69 \\
\hline & $(0.0000)$ & $(0.0001)$ & $(0.0000)$ & $(0.0001)$ & $(0.0000)$ & $(0.0000)$ & $(0.0238)$ \\
\hline & \multicolumn{7}{|c|}{ Panel B: Fixed Effect versus Random Effect } \\
\hline$\beta_{0}$ & $7.593 * * *$ & 30.374 & $1.321 * *$ & 7.930 & $2.059 * * *$ & 2.498 & -44.741 \\
\hline$\beta_{\mathrm{VAIC}}$ & $0.124 * * *$ & $1.873 * * *$ & $0.042 * * *$ & $0.485 * * *$ & 0.002 & $0.158 * * *$ & 0.991 \\
\hline$\beta$ VAIC $t$ & -0.007 & $0.587 * *$ & -0.007 & -0.108 & $0.002 * *$ & -0.032 & -0.024 \\
\hline \multicolumn{8}{|l|}{-1} \\
\hline$\beta_{\mathrm{LEV}}$ & $-4.790 * *$ & -8.870 & $-1.213 * *$ & $-9.840 *$ & $0.572 *$ & $-4.567 * * *$ & 58.189 \\
\hline$\beta_{\mathrm{AGE}}$ & -0.031 & -1.047 & 0.087 & 0.460 & 0.022 & $-0.272 *$ & $-75.361 * * *$ \\
\hline$\beta_{\text {SIZE }}$ & $-0.206^{*}$ & -0.950 & -0.029 & 0.072 & $-0.138^{* * *}$ & $0.228 * *$ & $19.207 * * *$ \\
\hline $\mathrm{R}^{2}$ & 0.2305 & 0.2137 & 0.2610 & 0.2571 & 0.4779 & 0.4218 & 0.2605 \\
\hline Hausman & 1.96 & 6.72 & 4.42 & 9.00 & 22.42 & 5.88 & 27.38 \\
\hline \multirow[t]{2}{*}{ Test } & $(0.8551)$ & $(0.2427)$ & $(0.4906)$ & $(0.1091)$ & $(0.0004)$ & $(0.3176)$ & $(0.0000)$ \\
\hline & \multicolumn{7}{|c|}{ Panel C: Generalized Methods of Moments (GMM) } \\
\hline$\beta_{0}$ & 5.217 & -114.021 & -4.060 & $-85.072 * *$ & -1.101 & $17.513 * *$ & 223.200 \\
\hline$\beta_{\mathrm{VAIC}}$ & $0.121 * *$ & $2.374 * * *$ & $0.064 * * *$ & $0.798 * * *$ & 0.012 & $0.102 * *$ & -0.268 \\
\hline$\beta$ VAIC $_{t-1}$ & -0.006 & -0.259 & 0.009 & 0.051 & 0.005 & $0.042 * *$ & -0.130 \\
\hline$\beta_{\mathrm{LEV}}$ & -2.450 & $146.247 *$ & $4.625^{*}$ & $88.129 * *$ & $2.808 * *$ & $-18.686 * *$ & -162.640 \\
\hline$\beta_{\mathrm{AGE}}$ & 0.020 & 2.303 & $0.234 * * *$ & $2.477 * * *$ & 0.049 & $-0.485 * * *$ & $-5.564 *$ \\
\hline$\beta_{\mathrm{SIZE}}$ & $-0.198 * *$ & -1.797 & $-0.074 *$ & -0.273 & $-0.055 * * *$ & 0.121 & -3.387 \\
\hline GMM & 0.386984 & 1.62558 & 3.00456 & 6.89425 & 7.15872 & 2.12942 & 1.52526 \\
\hline Value & $(0.5339)$ & $(0.2023)$ & $(0.0830)$ & $(0.0086)$ & $(0.0075)$ & $(0.1445)$ & $(0.2168)$ \\
\hline Hansen's & 3.62754 & 6.53301 & 6.9301 & 9.68788 & 25.6933 & 9.97193 & 10.6324 \\
\hline $\mathrm{Chi}^{2}$ & $(0.1630)$ & $(0.3810)$ & $(0.3130)$ & $(0.7900)$ & $(0.0000)$ & $(0.0068)$ & $(0.0049)$ \\
\hline
\end{tabular}

Note: *denotes $10 \%$ significant, $* *$ denotes $5 \%$ significant, $* * *$ denotes $1 \%$ significant 


\section{Macrothink Institute ${ }^{\text {m }}$}

This study earlier discussed the influence of lagged IC on corporate performance, thus formulated model-02 to investigate the relationship between lagged VAIC and Bangladeshi commercial banks performance. In Table-5, model-02 presents the results of these investigations. In panel $\mathrm{A}$ and $\mathrm{B}$, empirical results indicate that there are negative and insignificant relationships between previous year's VAIC and current year corporate performances except ROE, GO and TQ. The coefficient of $\mathrm{VAIC}_{\mathrm{t}-1}$ with these three measures is positively significant at $5 \%$ level. The $\mathrm{R}^{2}$ values are also at a moderate level as in model-01. The result of the panel-C (GMM method) indicates VAIC $_{t-1}$ has a positive relationship with ROC, EPS, TQ and EP but the relationships are not significant except for EP. The rest of the performance measures are negative and insignificant with $\mathrm{VAIC}_{\mathrm{t}-1 \text {. Here the study accepted }}$ five performance measures as the random effect model and two as the fixed effect model based on the Hausman test. The Hansen's $\mathrm{Chi}^{2}$ shows there is no correlation between instruments and error term in the model of ROA, ROE, ROC, and EPS, and which is same as model-01.

Although there is some positive and significant influencing power of $\mathrm{VAIC}_{\mathrm{t}-1}$ on banks performance measures the overall result of model-02 is not supportive enough to accept the hypothesis H.1aL. Therefore, it can be concluded the previous year's VAIC cannot influence the current year corporate performance of Bangladeshi banks.

Table 6. Result of VAIC components and corporate performance

\begin{tabular}{|c|c|c|c|c|c|c|c|}
\hline & \multicolumn{7}{|l|}{ Model 03} \\
\hline & ROA & ROE & ROC & EPS & TQ & EP & $\mathrm{GO}$ \\
\hline & \multicolumn{7}{|c|}{ Panel A: Pool Regression } \\
\hline$\beta_{0}$ & $7.366^{* * *}$ & 10.520 & .592 & -1.929 & $1.595 * * *$ & $5.721 * * *$ & -11.632 \\
\hline$\beta_{\mathrm{HCE}}$ & $-0.272 *$ & -1.773 & -0.054 & -0.380 & 0.002 & 0.175 & 2.966 \\
\hline$\beta_{\mathrm{SCE}}$ & $2.914 * *$ & 21.394 & 0.531 & 2.538 & -0.096 & 0.404 & 4.680 \\
\hline$\beta_{\mathrm{CEE}}$ & $7.039 *$ & $26.687 * * *$ & $4.915^{* * *}$ & $9.812 * * *$ & $0.875^{*}$ & $-5.553 *$ & -6.389 \\
\hline$\beta_{\text {LEV }}$ & $-6.064 * * *$ & -1.581 & $-0.881 *$ & -4.144 & 0.242 & $-5.899 * * *$ & $77.636 * *$ \\
\hline$\beta_{\mathrm{AGE}}$ & -0.165 & $-2.742 * *$ & 0.039 & -0.238 & -0.004 & $-0.205 * *$ & 617 \\
\hline$\beta_{\text {SIZE }}$ & -0.132 & -0.127 & -0.001 & $0.540 * *$ & $-0.064 * * *$ & 0.034 & -3.410 \\
\hline $\mathrm{R}^{2}$ & 0.2325 & 0.2164 & 0.3216 & 0.3315 & 0.2706 & 0.3608 & 0.0955 \\
\hline \multirow[t]{3}{*}{ F - Value } & 6.72 & 6.12 & 10.51 & 10.99 & 8.22 & 12.51 & 2.34 \\
\hline & $(0.0000)$ & $(0.0000)$ & $(0.0000)$ & $(0.0000)$ & $(0.0000)$ & $(0.0000)$ & $(0.0350)$ \\
\hline & \multicolumn{7}{|c|}{ Panel B: Fixed Effect versus Random Effect } \\
\hline$\beta_{0}$ & $6.611 * * *$ & 14.950 & $1.116^{*}$ & $11.185^{*}$ & $2.140 * * *$ & 2.827 & -24.229 \\
\hline$\beta_{\mathrm{HCE}}$ & -0.126 & -1.112 & 0.013 & 0.384 & 0.012 & $0.183^{*}$ & 4.594 \\
\hline$\beta_{\mathrm{SCE}}$ & $2.096^{*}$ & 17.985 & 0.097 & -0.373 & -.075 & -0.193 & -26.413 \\
\hline$\beta_{\mathrm{CEE}}$ & 4.719 & $17.678 * * *$ & $3.010 * *$ & $6.493 *$ & 0.080 & -1.733 & -2.405 \\
\hline$\beta_{\mathrm{LEV}}$ & $-4.748 * *$ & -4.935 & $-1.158 * *$ & $-20.278 * * *$ & 0.546 & $-4.576^{* * *}$ & 51.653 \\
\hline$\beta_{\mathrm{AGE}}$ & -0.118 & $-2.722 * *$ & 0.049 & -1.924 & 0.039 & -0.259 & $-72.331 * * *$ \\
\hline$\beta_{\text {SIZE }}$ & -0.166 & -0.200 & -0.013 & 1.144 & $-0.145 * * *$ & $0.198 *$ & $18.079 * *$ \\
\hline $\mathrm{R}^{2}$ & 0.2399 & 0.2706 & 0.3446 & 0.2909 & 0.4887 & 0.4035 & 0.2736 \\
\hline
\end{tabular}




$\begin{array}{llllllll}\text { Hausman } & 10.07 & 12.33 & 10.05 & 21.32 & 32.48 & 5.19 & 22.18 \\ \text { Test } & (0.1219) & (0.0550) & (0.1227) & (0.0016) & (0.0000) & (0.5197) & (0.0011)\end{array}$

Panel C: Generalized Methods of Moments (GMM)

\begin{tabular}{llllllll}
$\beta_{0}$ & $9.784^{*}$ & 37.913 & 0.614 & -15.456 & -0.278 & $9.781^{*}$ & 122.011 \\
$\beta_{\mathrm{HCE}}$ & $-0.266^{* *}$ & -2.079 & -0.062 & -0.362 & -0.005 & $0.182^{*}$ & 1.574 \\
$\beta_{\mathrm{SCE}}$ & $2.600^{* *}$ & 24.177 & $0.774^{*}$ & 3.599 & 0.028 & 0.103 & -6.563 \\
$\beta_{\mathrm{CEE}}$ & $8.167^{* *}$ & $17.329^{* * *}$ & $2.780^{* *}$ & $8.810^{* * *}$ & $1.096^{* *}$ & $-6.614^{* *}$ & 4.005 \\
$\beta_{\mathrm{LEV}}$ & -8.748 & -25.506 & -0.571 & 12.778 & $1.898^{* *}$ & $-10.27^{* *}$ & -52.363 \\
$\beta_{\mathrm{AGE}}$ & -0.239 & $-3.255^{* *}$ & $0.091^{* *}$ & 0.280 & 0.015 & $-0.261^{* *}$ & -2.341 \\
$\beta_{\mathrm{SIZE}}$ & -0.100 & -0.504 & -0.044 & 0.199 & $-0.044 * * *$ & 0.0591 & $-3.958^{*}$ \\
GMM & 0.398358 & 0.363579 & 0.075802 & 1.22539 & 7.25251 & 0.384234 & 0.369549 \\
Value & $(0.5279)$ & $(0.5465)$ & $(0.7831)$ & $(0.2683)$ & $(0.0071)$ & $(0.5353)$ & $(0.5433)$ \\
Hansen's & 2.5365 & 10.9131 & 11.744 & 19.4454 & 30.2097 & 7.15695 & 14.4656 \\
Chi ${ }^{2}$ & $(0.2813)$ & $(0.0043)$ & $(0.0028)$ & $(0.0001)$ & $(0.0000)$ & $(0.0279)$ & $(0.0007)$ \\
\hline
\end{tabular}

Note: *denotes $10 \%$ significant, $* *$ denotes $5 \%$ significant, $* * *$ denotes $1 \%$ significant

Model-03 examined how the banks' performances of Bangladesh are impacted by VAIC components namely HCE, SCE, and CEE. It is shown in table- 6 that the maximum number of banks performance measures are positively and significantly impacted by CEE as a component of VAIC. The study finds in polled regression that HCE only has a negative impact on ROA at $10 \%$ significance level. SCE is positively related to ROA and statistically significant at 5\% level. Other coefficients of HCE and SCE are not statistically significant. It is discovered that HCE and SCE have a very small degree of influence on banks performance. Whereas, CEE has a positive and significant impact on maximum performance measures of Bangladeshi banks. It was found that ROA, ROE, ROC, EPS, TQ are positively related while $\mathrm{EP}$ and GO is negatively related to CEE, and all are statistically significant except GO.

The fixed and random effect methods also presented almost similar findings as polled regression. Here the significant effect of CEE is reduced a little due to consideration of the heterogeneity problem. Where, HCE and SCE are positively significant with EP and ROA respectively, and none of the others are statistically significant with performance measures. Only three performance measures namely ROE, ROC and EPS are significantly influenced by CEE. The Hausman test is used as before to estimate the appropriate model. The model coefficient of determination $\left(\mathrm{R}^{2}\right)$ is significantly moved forward in this method than in polled regression. Notably, $\mathrm{R}^{2}$ values of all models did not substantially increase when the IC components are disaggregated as compare to $\mathrm{R}^{2}$ values of VAIC as a whole.

In panel-C, the study revealed a significant impact of HCE is on ROA and EP, and SCE is on ROA and ROC as performance measures of banks. While, CEE is positively connected with ROA, ROE, ROC, EPS, TQ and it is negatively connected with EP and GO. It is also statistically significant at varying levels with all performance measures except GO. It is revealed that an individual component of IC has more explanatory power than when aggregated into VAIC. 


\section{Macrothink Institute ${ }^{\mathrm{TM}}$}

The result of model-3 is partly similar to Chen et al (2005); Dzenopoljac et al (2017); Ozkan et al (2017). For example, Ozkan et al (2017) observed that financial performance is positively influenced by HCE and CEE. Further Dzenopoljac et al (2017) revealed the structural and physical capital creates high impacts on earnings and profitability. This study also found that only CEE has a strong ability to positively influence banks performance. However, the results disagree to that of Ciğer and Topsakal (2016) and Antonio et al (2016) in this aspect. Here, the coefficient of CEE is notably greater than other coefficients which also prove the dominating power to contribute to corporate performance. The dominant power of CEE suggested investments in more physical and financial capital obtain higher bank performance in Bangladesh.

Thus, it is proven that DSE listed Bangladeshi banks performance is diversely motivated by IC components and which is supportive of the main research question. Therefore the result supports the acceptance of hypothesis H.2c and rejection the hypotheses H.2a and H.2b.

Table 7. Result of previous year's VAIC components and corporate performance

\begin{tabular}{|c|c|c|c|c|c|c|c|}
\hline & $\begin{array}{l}\text { Model } 04 \\
\text { ROA }\end{array}$ & ROE & ROC & EPS & TQ & EP & GO \\
\hline & Panel A: Po & ol Regressic & & & & & \\
\hline$\beta_{0}$ & $7.348 * * *$ & 11.751 & 0.548 & -2.113 & $1.608 * * *$ & $5.882 * * *$ & -16.016 \\
\hline$\beta_{\mathrm{HCE}}$ & $-0.249 *$ & -1.347 & -0.041 & -0.201 & 0.006 & 0.166 & 4.633 \\
\hline$\beta_{\mathrm{SCE}}$ & $2.750 * *$ & 1.285 & 0.401 & 1.167 & -.115 & 0.445 & 5.570 \\
\hline$\beta_{\mathrm{CEE}}$ & 7.534 & $37.883 * * *$ & $5.080 * * *$ & $10.112 * * *$ & $0.993^{*}$ & -3.295 & $-8.163 * *$ \\
\hline$\beta_{\mathrm{HCE} \text { - } 1}$ & -0.098 & -0.797 & -0.059 & $-0.691 *$ & 0.003 & 0.071 & $-5.030 *$ \\
\hline$\beta_{\mathrm{SCE} t-1}$ & 0.807 & 2.660 & 0.542 & 5.546 & -0.073 & -0.624 & 27.273 \\
\hline$\beta_{\mathrm{CEE} \mathrm{t} \mathrm{-} 1}$ & -0.807 & -20.018 & -0.020 & -4.068 & -0.099 & -3.923 & $18.983 * *$ \\
\hline$\beta_{\mathrm{LEV}}$ & $-6.245^{* * *}$ & -4.068 & $-0.976 * *$ & -5.428 & 0.233 & $-5.932 * * *$ & $74.820 * *$ \\
\hline$\beta_{\mathrm{AGE}}$ & -0.161 & $-2.719 * *$ & 0.034 & -0.259 & -0.008 & $-0.195 * *$ & 0.132 \\
\hline$\beta_{\text {SIZE }}$ & -0.132 & 0.021 & 0.000 & $0.562 * *$ & $-0.060 * * *$ & 0.042 & -3.371 \\
\hline $\mathrm{R}^{2}$ & 0.2372 & 0.2323 & 0.3306 & 0.3559 & 0.2833 & 0.3704 & 0.1431 \\
\hline F - Value & $\begin{array}{l}4.46 \\
(0.0000)\end{array}$ & $\begin{array}{l}4.34 \\
(0.0001)\end{array}$ & $\begin{array}{l}7.08 \\
(0.0000)\end{array}$ & $\begin{array}{l}7.92 \\
(0.0000)\end{array}$ & $\begin{array}{l}5.67 \\
(0.0000)\end{array}$ & $\begin{array}{l}8.43 \\
(0.0000)\end{array}$ & $\begin{array}{l}2.39 \\
(0.0153)\end{array}$ \\
\hline
\end{tabular}

Panel B: Fixed Effect versus Random Effect

$\begin{array}{llllllll}\beta_{0} & 6.584 * * * & 16.218 & 1.475^{* *} & 11.631 * & 2.121 * * * & 1.641 & -10.857 \\ \beta_{\mathrm{HCE}} & -0.124 & -0.847 & 0.036 & 0.389 & 0.014 & 0.182^{*} & 5.392 * \\ \beta_{\mathrm{SCE}} & 2.056 & 17.231 & 0.033 & -0.217 & -0.084 & -0.190 & -6.756 \\ \beta_{\mathrm{CEE}} & 5.256 & 28.898 * * * & 1.046 & 5.221 & -0.010 & 1.450 & -8.912 * \\ \beta_{\mathrm{HCE} \mathrm{t-1}} & 0.016 & -0.409 & 0.011 & -0.073 & 0.016 & 0.026 & -4.382 \\ \beta_{\mathrm{SCE} \mathrm{t-1}} & 0.012 & -0.762 & -0.086 & 1.049 & -0.134 & -0.431 & 24.979 \\ \beta_{\mathrm{CEE} \mathrm{t}-1} & -2.146 & -22.176 & -1.804 * & -19.930 * * & -0.143 & -3.829 & 19.631 * * \\ \beta_{\mathrm{LEV}} & -4.644 * * & -6.674 & -1.910 * * & -21.465 * * * & 0.580 * & -4.172 * & 83.883 * * \\ \beta_{\mathrm{AGE}} & -0.101 & -2.711 * * & -0.281 & -2.746 & 0.032 & -0.562 & -0.322\end{array}$




\begin{tabular}{llllllll}
\hline$\beta_{\text {SIZE }}$ & -0.174 & -0.021 & 0.107 & $1.423^{*}$ & $-0.140^{* * *}$ & 0.371 & $-4.423^{*}$ \\
$\mathrm{R}^{2}$ & 0.2404 & 0.2950 & 0.3370 & 0.3285 & 0.4874 & 0.2954 & 0.1889 \\
Hausman & 10.25 & 6.18 & 27.25 & 20.51 & 21.68 & 5.93 & 25.79 \\
Test & $(0.3305)$ & $(0.7216)$ & $(0.0013)$ & $(0.0150)$ & $(0.0100)$ & $(0.7468)$ & $(0.0022)$
\end{tabular}

Panel C: Generalized Methods of Moments (GMM)

\begin{tabular}{llllllll}
$\beta_{0}$ & $10.306^{*}$ & 34.083 & 1.113 & -13.451 & 0.207 & 7.115 & 124.594 \\
$\beta_{\text {HCE }}$ & $-0.246^{*}$ & -1.483 & -0.060 & -0.277 & -0.002 & 0.182 & 4.202 \\
$\beta_{\text {SCE }}$ & $2.414^{*}$ & 19.364 & 0.608 & 1.838 & 0.029 & 0.265 & -24.034 \\
$\beta_{\text {CEE }}$ & 8.341 & $45.087 * * *$ & $3.790 * *$ & $10.603 * * *$ & 0.687 & -4.949 & $-9.728^{*}$ \\
$\beta_{\text {HCE t }-1}$ & -0.124 & -0.962 & -0.040 & -0.467 & 0.022 & 0.050 & $-7.608^{* *}$ \\
$\beta_{\text {SCE t }-1}$ & 1.108 & 6.907 & 0.550 & 5.000 & -0.252 & -0.537 & $52.322^{*}$ \\
$\beta_{\text {CEE t }-1}$ & -0.641 & -41.815 & -1.176 & -16.883 & 0.329 & -3.868 & $17.389^{*}$ \\
$\beta_{\text {LEV }}$ & $-9.449 *$ & -24.153 & -1.189 & 9.285 & $1.506^{* *}$ & $-7.472 *$ & -73.206 \\
$\beta_{\text {AGE }}$ & -0.241 & $-3.026^{* *}$ & $0.083^{* *}$ & 0.284 & 0.000 & $-0.214 * *$ & -3.715 \\
$\beta_{\text {SIZE }}$ & -0.112 & -0.324 & $-0.048^{*}$ & 0.229 & $-0.043^{* * *}$ & 0.071 & -3.202 \\
GMM & 0.590 & 0.301 & 0.000 & 1.137 & 5.721 & 0.009 & 0.944 \\
Value & $(0.4424)$ & $(0.5829)$ & $(0.9902)$ & $(0.2861)$ & $(0.0168)$ & $(0.9244)$ & $(0.3312)$ \\
Hansen's & 2.22388 & 10.46 & 11.4815 & 20.8434 & 34.9213 & 8.39751 & 11.7263 \\
Chi ${ }^{2}$ & $(0.3289)$ & $(0.0054)$ & $(0.0032)$ & $(0.0000)$ & $(0.0000)$ & $(0.0150)$ & $(0.0028)$ \\
\hline
\end{tabular}

Note: $*$ denotes $10 \%$ significant, $* *$ denotes $5 \%$ significant, $* * *$ denotes $1 \%$ significant

Table-7 shows the relationship between the previous year's IC components and the current year banks' performance in Bangladesh. It is found from this empirical result that the previous year's CEE has a negative relationship with all performance measures except GO across the panels. These relationships are also statistically insignificant except for GO and EPS. $\mathrm{CEE}_{\mathrm{t}-1}$ has a very high positive and significant impact on GO across the panels used here, and a negative and significant impact on ROC and EPS when used with fixed and random effect methods.

$\mathrm{HCE}_{\mathrm{t}-1}$ and $\mathrm{SCE}_{\mathrm{t}-1}$ have a diverse relationship with all performance measures used across the panels. These relationships are mostly insignificant except for with GO. $\mathrm{HCE}_{\mathrm{t}-1}$ has a negative and significant impact on GO when the GMM method is applied. $\mathrm{R}^{2}$ values across the methods increased a very small portion of all performance measures. It means that when the method is changed, its explanatory power has increased. The study used Hausman test, GMM values, and Hansen $\mathrm{chi}^{2}$ as decision tools as before.

Overall the results offer very little support to the acceptance of the hypothesises set earlier. Hence, the study rejects the hypotheses H.2aL, H.2bL, and H.2cL though $\mathrm{CEE}_{\mathrm{t}-1}$ has very little influencing power on banks' performance. After all, it is demonstrated that none of the lagged IC components could create a positive impact on the Bangladeshi commercial banks' performance. 
Table 8. Results of the moderating power of IC components and corporate performance

\begin{tabular}{llllllll}
\hline & Model 06 & & & & & \\
& ROA & ROE & ROC & EPS & TQ & EP & GO \\
\hline$\beta_{0}$ & -1.318 & -15.116 & -0.273 & $-5.802^{*}$ & -0.052 & -0.696 & 34.388 \\
$\beta_{\mathrm{HCE}}$ & -0.293 & 0.223 & 0.081 & -0.448 & -0.037 & -0.101 & 0.758 \\
$\beta_{\mathrm{SCE}}$ & 3.023 & 17.041 & -0.146 & 8.653 & 0.209 & 1.652 & -68.724 \\
$\beta_{\mathrm{CEE}}$ & 5.626 & 183.036 & 1.804 & 147.628 & 2.755 & 1.382 & -1035.659 \\
$\beta_{\mathrm{HCE}{ }^{*} \mathrm{CEE}}$ & 0.695 & -41.638 & $3.336^{* *}$ & 8.433 & 1.130 & 7.025 & -72.155 \\
$\beta_{\mathrm{SCE}{ }^{*} \mathrm{CEE}}$ & $2.793 * * *$ & $4.376^{* * *}$ & $7.960^{* *}$ & $-2.789 * *$ & -8.271 & 3.600 & $1.336 * *$ \\
$\mathrm{R}^{2}$ & 0.9480 & 0.8291 & 0.2150 & 0.2584 & 0.3070 & 0.9600 & 0.4850 \\
$\mathrm{~F}_{-}$Value & 2.81 & 6.00 & 7.34 & 9.34 & 0.85 & 6.53 & 1.36 \\
& $(0.0191)$ & $(0.0000)$ & $(0.0000)$ & $(0.0000)$ & $(0.5176)$ & $(0.0000)$ & $(0.2415)$ \\
\hline
\end{tabular}

Note: $*$ denotes $10 \%$ significant, $* *$ denotes $5 \%$ significant, $* * *$ denotes $1 \%$ significant

Table 9. Results of the moderating power of IC components when added lagged effect of VAIC components

\begin{tabular}{|c|c|c|c|c|c|c|c|}
\hline & Model 07 & & & & & & \\
\hline & ROA & $\mathrm{ROE}$ & ROC & EPS & TQ & EP & GO \\
\hline$\beta_{0}$ & -1.500 & -15.072 & -0.371 & $-6.745^{* *}$ & -0.044 & -0.653 & 28.170 \\
\hline$\beta_{\mathrm{HCE}}$ & -0.254 & 1.179 & 0.097 & -0.177 & -0.037 & -0.107 & 6.279 \\
\hline$\beta_{\mathrm{SCE}}$ & 2.710 & 16.078 & -0.294 & 7.046 & 0.238 & 1.820 & -86.130 \\
\hline$\beta_{\mathrm{CEE}}$ & 5.445 & 249.750 & 1.593 & $153.238^{*}$ & 3.517 & 7.718 & $-1328.024 *$ \\
\hline$\beta_{\mathrm{HCE} \mathrm{t}-1}$ & -0.107 & -0.695 & -0.056 & $-0.621^{*}$ & 0.004 & 0.040 & $-5.775 * *$ \\
\hline$\beta_{\text {SCE t }-1}$ & 0.936 & 0.729 & 0.487 & 4.838 & -0.057 & -0.297 & 37.569 \\
\hline$\beta_{\text {CEE t - } 1}$ & -1.277 & -27.080 & -0.282 & -7.402 & -0.174 & -3.948 & $193.874 * *$ \\
\hline$\beta_{\mathrm{HCE} * \mathrm{CEE}}$ & .193 & -51.393 & 3.420 & 5.837 & 1.221 & $7.233 * * *$ & -103.365 \\
\hline$\beta_{\mathrm{SCE}^{*} \mathrm{CEE}}$ & $1.153 * *$ & $15.451 * * *$ & $19.061^{* *}$ & $-19.162 * *$ & -9.720 & $45.664 * *$ & $2.540 * *$ \\
\hline $\mathrm{R}^{2}$ & 0.7000 & 0.8005 & 0.2600 & 0.2888 & 0.3837 & 0.5820 & 0.6665 \\
\hline F- Value & $\begin{array}{l}1.84 \\
(0.0753)\end{array}$ & $\begin{array}{l}4.34 \\
(0.0001)\end{array}$ & $\begin{array}{l}4.75 \\
(0.0000)\end{array}$ & $\begin{array}{l}6.60 \\
(0.0000)\end{array}$ & $\begin{array}{l}0.65 \\
(0.7366)\end{array}$ & $\begin{array}{l}4.21 \\
(0.0002)\end{array}$ & $\begin{array}{l}1.94 \\
(0.0594)\end{array}$ \\
\hline
\end{tabular}

Lastly, model 06 and 07 were adopted to examine the moderating power of HCE and SCE on CEE to uplift corporate performance. The results revealed a moderating ability of HCE on CEE of banks performance at different levels. The interaction between HCE and CEE is mostly insignificant relating to banks performance measures used here, except for ROC in model-06 and EP in model-07. These two measures (ROC and EP) have only been positively and significantly impacted by HCE*CEE. It implies that the interaction of HCE and CEE has very low ability to influence corporate performance. The interaction of SCE and CEE is significant in both models at different levels. It is found that SCE*CEE is significant at $1 \%$ level with ROA, ROE, at $5 \%$ level with ROC, EPS and GO in the model which only used the 
current year's IC components. It has also found the significant level of SCE and CEE interaction for ROE to be $1 \%$ and $5 \%$ for ROA, ROC, EPS, EP and GO in the model that used current and previous year's IC components. It is proven that SCE has greater moderating power on CEE to the improvement of banks' performance. Noticeably, the coefficients of SCE*CEE are very high; which also demonstrates its ability to contribute to banks performance. It also has a negative relationship with some performance measures like-EPS and TQ.

The result of SCE*CEE is strong enough to support the acceptance of hypothesis H.3b, and the results of $\mathrm{HCE}^{*} \mathrm{CEE}$ do not support to acceptance of the hypothesis H.3a. The explanatory powers of the models are higher than previous models used in this study. For instance, the $\mathrm{R}^{2}$ value of ROA $94 \%$, ROE $82 \%$, EP $96 \%$, GO $48 \%$, and the rest of the performance measures are at a moderate level in model-06. Furthermore, in model-07 $\mathrm{R}^{2}$ values are somewhat less than that of model-06. It implies that the interaction between HCE and CEE, and SCE and CEE have added noticeable explanatory power compared to other models used in this paper. These outcomes strongly support the presence of a probable moderating effect of SCE on CEE about on corporate performance. Hence, it is suggested the commercial banks of Bangladesh should make more investment in structural capital rather than in human capital which will create very close conjunction with physical and financial assets; that will in turn into the bank's performance.

\section{Conclusion and Policy Implication}

Due to the significance of IC and corporate performance in the modern business world, this paper intended to explore the association of IC on Bangladeshi commercial banks performance. To do this, the study adopted different econometric models and methods. For instance, firstly a pool regression method is estimated which does not consider the unobservable heterogeneity and the endogeneity problems. Afterward, to remove the unobservable heterogeneity problems the study used a fixed and random effect method in a static panel data model. Lastly, to limit the endogeneity problems of explanatory variables the study used GMM in a dynamic panel data model. The entire investigated results of this study are presented in the table- 10 .

Table 10. Testing hypothesis at a glance based on the results

\begin{tabular}{|c|c|c|c|c|c|c|c|c|c|}
\hline & $\begin{array}{l}\text { Used banks } \\
\text { Performance } \\
\text { Indicators }\end{array}$ & ROA & ROE & ROC & EPS & TQ & $\mathrm{EP}$ & GO & $\begin{array}{l}\text { Hypothesis } \\
\text { accepted/ } \\
\text { rejected }\end{array}$ \\
\hline Hypothesis & $\begin{array}{l}\text { Explanatory } \\
\text { variables }\end{array}$ & \multicolumn{8}{|c|}{$\begin{array}{l}\text { The significant/insignificant result of each model shows for } \\
\text { different methods separately. The methods are Polled regression, } \\
\text { Fixed effect and Random effect, and GMM respectively. Here, } \\
(\sqrt{ }) \text { means significant and }(X) \text { means insignificant. }\end{array}$} \\
\hline H.1a & VAIC & $\sqrt{ } \sqrt{ }$ & $\sqrt{ } \sqrt{ }$ & $\sqrt{ } \sqrt{ }$ & $\sqrt{ } \sqrt{x}$ & XXX & $\sqrt{ } \sqrt{1}$ & XXX & Accepted \\
\hline
\end{tabular}




\begin{tabular}{|c|c|c|c|c|c|c|c|c|c|}
\hline H.1aL & $\mathrm{VAIC}_{\mathrm{t}-1}$ & XXX & $\sqrt{ } \sqrt{X}$ & XXX & XXX & $X \sqrt{ } X$ & $X X \sqrt{ }$ & $\sqrt{ } \mathrm{XX}$ & Rejected \\
\hline H.2a & HCE & $\sqrt{ } \mathrm{X} \sqrt{ }$ & XXX & XXX & XXX & XXX & $\mathrm{X} \sqrt{ } \sqrt{ }$ & XXX & Rejected \\
\hline H. $2 b$ & SCE & $\sqrt{ } \sqrt{ }$ & XXX & $X X \sqrt{ }$ & XXX & XXX & XXX & XXX & Rejected \\
\hline H. $2 \mathrm{c}$ & CEE & $\sqrt{ } \mathrm{X} \sqrt{ }$ & $\sqrt{ } \sqrt{ } \sqrt{ }$ & $\sqrt{ } \sqrt{ }$ & $\sqrt{ } \sqrt{ }$ & $\sqrt{ } \mathrm{X} \sqrt{ }$ & $\sqrt{ } \mathrm{X} \sqrt{ }$ & XXX & Accepted \\
\hline H. $2 \mathrm{aL}$ & $\mathrm{HCE}_{\mathrm{t}-1}$ & XXX & XXX & XXX & $\sqrt{X X}$ & XXX & XXX & $\sqrt{ } \mathrm{x} \sqrt{ }$ & Rejected \\
\hline H.2bL & $\mathrm{SCE}_{\mathrm{t}-1}$ & XXX & XXX & XXX & XXX & XXX & XXX & $X X \sqrt{ }$ & Rejected \\
\hline H. $2 \mathrm{cL}$ & $\mathrm{CEE}_{\mathrm{t}-1}$ & XXX & XXX & $x \sqrt{ } x$ & $x \sqrt{ } x$ & XXX & XXX & $X \sqrt{ } \sqrt{ }$ & Rejected \\
\hline
\end{tabular}

Model - 6

$\begin{array}{llllllllll}\text { H.3a } & \text { HCE*CEE } & \text { X } & \text { X } & \sqrt{ } & \text { X } & \text { X } & \text { X } & \text { X } & \text { Rejected } \\ \text { H.3b } & \text { SCE*CEE } & \sqrt{ } & \sqrt{ } & \sqrt{ } & \sqrt{ } & \text { X } & \text { X } & \sqrt{ } & \text { Accepted }\end{array}$

Model - 7

$\begin{array}{lllllllllll}\text { H.3a } & \text { HCE*CEE } & X & X & X & X & X & \sqrt{ } & X & \text { Rejected }\end{array}$

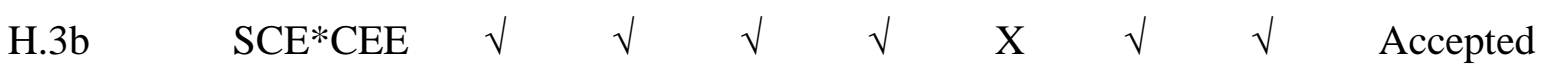

[Note: If the explanatory variable is positively significant with maximum number of performance indicators, the specific hypothesis is accepted otherwise rejected.]

Table-10 shows that the hypotheses H.1a, H.2c and H.3b are accepted and all other hypotheses are rejected. It implies that VAIC as a whole and CEE as a component of VAIC have a greater impact on commercial banks performance. In addition, SCE has very high moderating power on $\mathrm{CEE}$ to banks performance. Although it is very difficult to generalize the findings of this study for other industries it assumes that the intellectual capital (IC) is directly and indirectly associated with the banking industry's performance.

The policy implication of the study is that the commercial banks of Bangladesh should increase their investment in intellectual capital for better performance as the study investigated a positive and significant impact of overall IC on the bank's performance. However, the investment should be on physical and financial assets rather than Human assets. Since the study investigated only CEE as components of VAIC has a positive and significant impact on performance. Further SEC has a positive and significant connection with CEE which can turn into the bank's performance. 


\section{Macrothink}

International Journal of Human Resource Studies

ISSN 2162-3058 2020, Vol. 10, No. 1

Among the contributions of this paper are that firstly it adds Bangladeshi Banking industry's results to the existing literature of this issue. Secondly, this study may be beneficial to the Bangladesh Bank (BB), Institutes of Bankers Bangladesh, all individual banks and other regulatory authorities whenever they considering new strategies for banks performance. Furthermore, it may be supportive when the relevant authorities are considering a new technique to measure the maximum use of intellectual capital.

\section{Limitations and Future Research}

The study is not out of limitations. Firstly this study considered only the Dhaka stock exchange (DSE) listed commercial banks of Bangladesh which is only about half of the total number of commercial banks operating in Bangladesh. Secondly, findings of the control factors are mixed and mostly insignificance with the performance of commercial banks. Therefore further research may consider all commercial banks of Bangladesh as sample and introduce other important control factors for getting more accurate findings.

\section{Appendix-A}

Figure 1

Figure 2

Figure 3
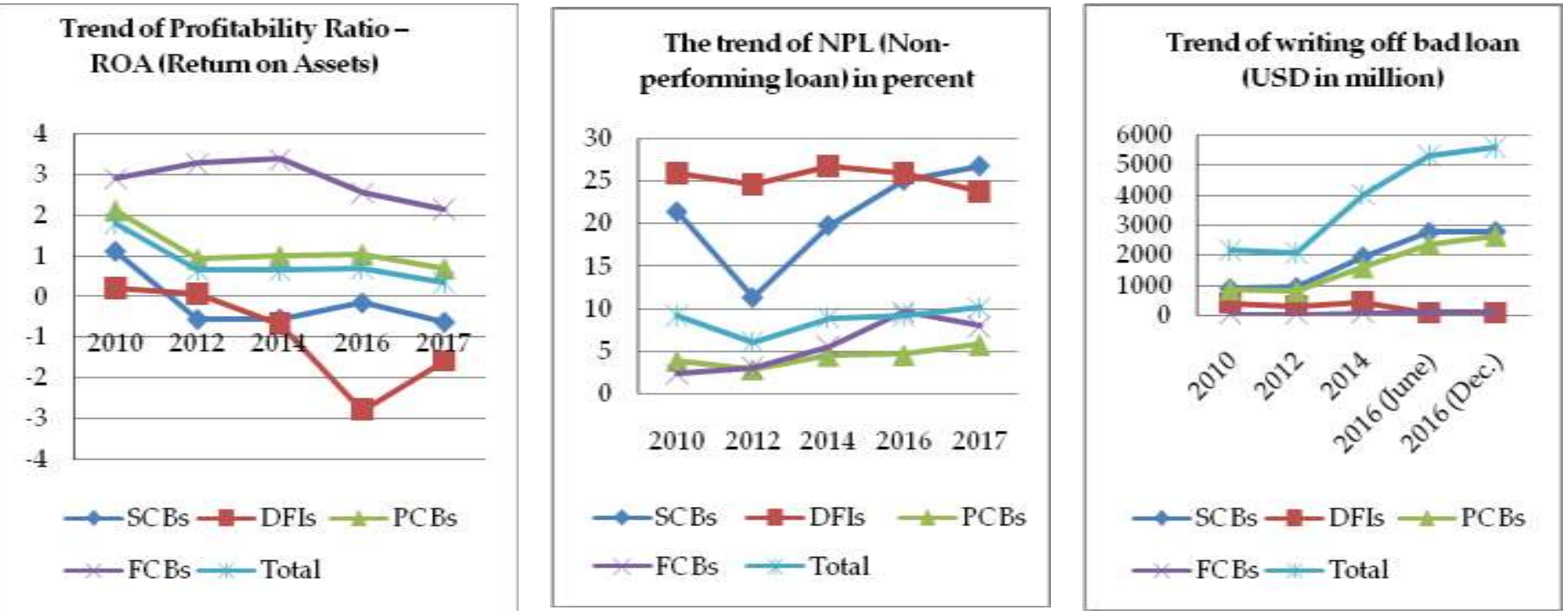

Source: Bangladesh Bank. Notes- SCBs: State-owned commercial banks; DFIs: Development financial institutions; PCBs: Privately owned commercial banks; FCBs: Foreign commercial banks

\section{References}

Alipour, M. (2012). The effect of intellectual capital on firm performance: an investigation of Iran insurance companies. Measuring Business Excellent, 16(1), 53-66. https://doi.org/10.1108/13683041211204671

Antonio, M., Claudio, P., Gabriele, S., \& Vincenzo, V. (2016). The impact of intellectual 
capital efficiency on commercial bank performance: Evidence from the US. Journal of Multinational Financial Management, $\quad 36(1), \quad 64-74$. https://doi.org/10.1016/j.mulfin.2016.04.003

Appuhami, B. A. R. (2007). The Impact of Intellectual Capital on Investors' Capital Gains on Shares: An Empirical Investigation of Thai Banking, Finance and Insurance Sector. International Management Review, 3(2), 14-25.

Bollen, L., Vergauwen, P., \& Schnieders, S. (2005). Linking Intellectual Capital and Intellectual Property to Company Performance. Management Decision, 43(9), 1161-1185. https://doi.org/10.1108/00251740510626254

Cabrita, M. R., \& Bontis, N. (2008). Intellectual capital and business performance in the Portuguese banking industry. International Journal of Technology Management, 43(1-3), 212-237. https://doi.org/10.1504/IJTM.2008.019416

Canibano, L., Garcia-Ayuso, M., \& Sanchez, M. P. (2000). Accounting for Intangibles: A Literature Review. The Journal of Accounting Literature, 19(1) 102-130.

Carter, D. A., Simkins, B. J., \& Simpson, W. J. (2003). Corporate Governance, Board Diversity and Firm Value. Financial Review, 38(1), 33-53. https://doi.org/10.1111/1540-6288.00034

Chen, M., Cheng, S., \& Hwang, Y. (2005). An Empirical Investigation of The Relationship between Intellectual Capital and Firms' Market Value and Financial Performance. Journal of Intellectual Capital, 6(2), 159-176. https://doi.org/10.1108/14691930510592771

Chu, S., Chan, K., Yu, K., Ng, H., \& Wong, W. (2011). An Empirical Study of the Impact of Intellectual Capital on Business Performance. Journal of Information\& Knowledge Management, 10(1), 11-21. https://doi.org/10.1142/S0219649211002791

Ciğer, A., \& Topsakal, Y. (2016). Intellectual Capital and Financial Performance: Case of Travel Agents. Asian Journal of Social Sciences and Management Studies, 3(3), 182-190. https://doi.org/10.20448/journal.500/2016.3.3/500.3.182.190

Clarke, M., Seng, D., \& Whiting, R. (2011). Intellectual Capital and Firm Performance in Australia. Journal of Intellectual Capital, 12(4), 505-530. https://doi.org/10.1108/14691931111181706

Cohen, S., \& Kaimenakis, N. (2007). Intellectual Capital and Corporate Performance in Knowledge-intensive SMEs. The Learning Organisation, 14(3), 241-262. https://doi.org/10.1108/09696470710739417

Dzenopoljac, V., Yaacoub, C., Elkanj, N., \& Bontis, N. (2017), Impact of intellectual capital on corporate performance: evidence from the Arab region. Journal of Intellectual Capital, 18(4), 884-903. https://doi.org/10.1108/JIC-01-2017-0014

Edvinsson, L., \& Malone, M. S. (1997). Intellectual Capital: Realising your Company's True Value by Finding its Hidden Brainpower, Harper Business, New York, NY. 


\section{Ml Macrothink}

International Journal of Human Resource Studies

ISSN 2162-3058

2020, Vol. 10, No. 1

Firer, S., \& Stainbank, L. (2003). Testing the relationship between Intellectual Capital and a company's performance: Evidence from South Africa. Meditarian Accountancy Research, 11(1), 25-44. https://doi.org/10.1108/10222529200300003

Firer, S., \& Williams, M. (2003). Intellectual Capital and Traditional Measures of Corporate Performance. Journal of Intellectual Capital, 4(3), 348-360. https://doi.org/10.1108/14691930310487806

Flamholtz, E. G. (1999). Current issues, recent advancements and future directions in human resource accounting. Journal of Human Resource Costing \& Accounting, 4(1), 11-20. https://doi.org/10.1108/eb029050

Gan, K., \& Saleh, Z. (2008). Intellectual Capital and Corporate Performance of Technology-Intensive Companies: Malaysia Evidence. Asian Journal of Business and Accounting, 1(1), 113-130.

Gopal, M. S., \& Mitra, G. (2016). Intellectual capital and firm performance in emerging economies: the case of India. Review of International Business \& Strategy, 26(3), 410-430. https://doi.org/10.1108/RIBS-03-2015-0019

Grant, J. (2007). Intellectual Capital, Performance and Industry in North American Firms, $P h D$ thesis, University of Otago, New Zealand.

Gujarati, D. (2004). Basic Econometrics, Mcgraw-Hill Edition

Hamzah, N., \& Ismail, M. N. (2008), The Importance of Intellectual Capital Management in the Knowledge-based Economy. Contemporary Management Research, 4(3), 237-262. https://doi.org/10.7903/cmr.1045

Hansen, L. P. (1982). Large Sample Properties of Generalized Method of Moments Estimators. Econometrica, 50(4), 1029-1054. https://doi.org/10.2307/1912775

Hausman, J. (1978). Specification tests in econometrics. Econometrica, 46, 1251-1271. https://doi.org/10.2307/1913827

Hryniewicz, O., \& Karpinski, J. (2014). Prediction of reliability - the pitfalls of using Pearson's correlation. Maintenance and Reliability, 16(3), 472-483.

Iazzolino, G., Migliano, G., \& Gregorace, E. (2013). Evaluating intellectual capital for supporting credit risk assessment: an empirical study. Investment Management and Financial Innovations, 10(2), 44-54.

Jaccard, J., \& Turrisi, R. (2003). Interaction Effects in Multiple Regression (2 ${ }^{\text {nd }}$ ed.), Sage University Paper Series on Quantitative Applications in the Social Sciences, Sage Publications, Thousand Oaks, California. https://doi.org/10.4135/9781412984522

Janosević, S., Dzenopoljac, V., \& Bontis, N. (2013). Intellectual Capital and Financial Performance in Serbia. Knowledge and Process Management, 20(1), 1-11. https://doi.org/10.1002/kpm.1404 


\section{MInstitute ${ }_{\text {Mink }}^{\text {Macrothink }}$}

International Journal of Human Resource Studies

ISSN 2162-3058

2020, Vol. 10, No. 1

Kaplan, R. S., \& Norton, D. P. (1992). The Balanced Scorecard: Measures that drives performance. Harvard Business review, 70(1), 71-79.

Kaplan, R. S., \& Norton, D. P. (2004). Strategy maps: Converting intangible assets into tangible outcomes, Harvard Business School Press, Boston.

Khalique, M., Bontis, N., Shaari, J. A. N., \& Yaacob, M. R. (2018). Intellectual capital and organizational performance in Malaysian knowledge-intensive SMEs. International Journal Learning and Intellectual Capital, 15(1), 20-36. https://doi.org/10.1504/IJLIC.2018.088345

Kujansivu, P., \& Lonnqvist, A. (2007). Investigating the Value and Efficiency of Intellectual $\begin{array}{lllll}\text { Capital. Journal of } & \text { Intellectual } & \text { Capital, } & 8(2), & 272-287\end{array}$ https://doi.org/10.1108/14691930710742844

Latif, A. A., \& Nicholas, A. (2016). Intellectual capital and bank productivity in emerging markets: evidence from Ghana. Management Decision, 54(3), 589-609. https://doi.org/10.1108/MD-01-2015-0025

Lu, W-M., Wang, W-K., \& Kweh, Q. (2014). Intellectual capital and performance in the Chinese life insurance industry. Omega (United Kingdom), 42(1), 65-74. https://doi.org/10.1016/j.omega.2013.03.002

Marr, B., Gray, D., \& Neely, A. (2003). Why do firms measure their intellectual capital? Journal of Intellectual Capital, 4(4), 441-464. https://doi.org/10.1108/14691930310504509

Mavridis, D. (2004). The Intellectual Capital Performance of the Japanese Banking Sector. Journal of Intellectual Capital, 5(1), 92-115. https://doi.org/10.1108/14691930410512941

Ousama, A. A., \& Fatima, A. H. (2015). Intellectual capital and financial performance of Islamic banks. International Journal of Learning and Intellectual Capital, 12(1), 1-15 https://doi.org/10.1504/IJLIC.2015.067822

Ozkan, N., Cakan, S., \& Kayacan, M. (2017). Intellectual capital and financial performance: A study of the Turkish Banking Sector. Borsa Istanbul Review, 17(3), 190-198. https://doi.org/10.1016/j.bir.2016.03.001

Porter, M. (1999). Creating advantage, Executive performance indicators of insurance sector. Excellence, 16(11), 13-14.

Pulic, A. (1998). Measuring the performance of intellectual potential in knowledge economy. paper presented at the 2nd McMaster World Congress on Measuring and Managing Intellectual Capital, 21-23 January, Hamilton.

Pulic, A. (2000). VAIC ${ }^{\mathrm{TM}}$ - An Accounting Tool for IC Management. International Journal Technology Management, 20(5), 702-714. https://doi.org/10.1504/IJTM.2000.002891

Puntillo, P. (2009). Intellectual Capital and business performance. Evidence from Italian banking industry. Journal of Corporate Finance, 4(12), 97-115.

Riahi-Belkaoui, A. (2003). Intellectual capital and firm performance of US multinational 
firms: a study of the resource-based and stakeholder views. Journal of Intellectual Capital, 4(2), 215-226. https://doi.org/10.1108/14691930310472839

Roos, G., Pike, S., \& Fernstrom, L. (2005). Managing Intellectual Capital in Practice, Butterworth-Heinemann, Jordan Hill, Oxford.

Roos, G., \& Roos, J. (1997). Measuring your company's intellectual performance. Long Range Planning, 30(3), 413-426. https://doi.org/10.1016/S0024-6301(97)90260-0

Sanchez, M. P., \& Elena, S. (2006). 'capital in universities improving transparency and internal management. Journal of Intellectual Capital, 7(4), 529-548. https://doi.org/10.1108/14691930610709158

Sardo, F., \& Serrasqueiro, Z. (2018). Intellectual capital, growth opportunities, and financial performance in European firms: Dynamic panel data analysis. Journal of Intellectual Capital, 19(4), 747-767. https://doi.org/10.1108/JIC-07-2017-0099

Scafarto, V., Ricci, F., \& Scafarto, F. (2016). Intellectual capital and firm performance in the global agribusiness industry: The moderating role of human capital. Journal of Intellectual Capital, 17(3), 530-552. https://doi.org/10.1108/JIC-11-2015-0096

Seleim, A., Ashour, A., \& Bontis, N. (2004). Intellectual capital in Egyptian software firms. The Learning Organization, 11(4/5), 332-346. https://doi.org/10.1108/09696470410538233

Sherif, M., \& Elsayed, M. (2015). The Impact of Intellectual Capital on Corporate Performance: Evidence from the Egyptian Insurance Market. International Journal of Innovation Management, 20(3), 1-38. https://doi.org/10.1142/S1363919616500341

Stewart, T. A. (1997). Intellectual Capital: The New Wealth of Organization, Bantam Doubleday Dell Publishing Group, New York, NY.

Sumedrea, S. (2013). Intellectual Capital and Firm Performance: A Dynamic Relationship in Crisis Time, Procedia Economics and Finance, 6(1), 137-144. https://doi.org/10.1016/S2212-5671(13)00125-1

Tan, H., Plowman, D., \& Hancock, P. (2008). The evolving research on intellectual capital. Journal of Intellectual Capital, 9(4), 85-608. https://doi.org/10.1108/14691930810913177

Tasawar, N., Haniffa, R., \& Hudaib, M. (2014). The impact of intellectual capital on corporate performance of islamic financial institutions. The Journal of Finance, 58(1), 519-526.

Torres, A., Silvana, S., \& Santos-Rodrigues, H. (2018). The impact of knowledge management factors in organizational sustainable competitive advantage. Journal of Intellectual Capital, 19(2), 453-472. https://doi.org/10.1108/JIC-12-2016-0143

Tovstiga, G., \& Tulugurova, E. (2007). Intellectual capital practices and performance in Russian enterprises. Journal of Intellectual Capital, 8(4), 695-707. https://doi.org/10.1108/14691930710830846 


\section{Macrothink}

International Journal of Human Resource Studies

ISSN 2162-3058 2020, Vol. 10, No. 1

Venkatraman, N., \& Ramanujam, V. (1986). Measurement of Business Performance in Strategy Research: A Comparison of Approaches. Academy of Management Review, 11(4), 801-814. https://doi.org/10.5465/amr.1986.4283976

Yalama, A., \& Coskun, M. (2007). Intellectual capital performance of quoted banks on the Istanbul stock exchange market. Journal of Intellectual Capital, 8(2), 256-271. https://doi.org/10.1108/14691930710742835

Zéghal, D., \& Maaloul, A. (2010). Analysing value added as an indicator of intellectual capital and its consequences on company performance. Journal of Intellectual Capital, 11(1), 39-60. https://doi.org/10.1108/14691931011013325

\section{Copyright Disclaimer}

Copyright for this article is retained by the author(s), with first publication rights granted to the journal.

This is an open-access article distributed under the terms and conditions of the Creative Commons Attribution license (http://creativecommons.org/licenses/by/4.0/). 